\title{
The Study of the USA in Finnish High Schools
}

By

Kari Sajavaara

University of Jyvaskyla

Ther'e are no American studies in Finnish high schools in the sense this term is normally understood. What information we have about studies of this nature is rather unreliable, because it is left to the teachers to decide which aspect of the teaching materials available they want to emphasize within the relatively vague limits of the curriculum. Thus the teacher is in the key position, and it is extremely important that the teachers are given information about the U.S. during their training and also after their training is finished.

\section{Curricula}

Most of the American material dealt with is part of the English language curriculum (practically all pupils do English as the major foreign language). The English language curriculum for Finnish schools requires that the material used for teaching English should include information about the culture and way of life of the English-speaking countries, which is mostly interpreted to mean Britain and at least the United States.

To a certain extent, U.S. material is dealt with in connection with history and teaching of literature. American history is nowadays given a fairly extensive coverage because modern history is given more emphasis than before. Some major American writers are represented by a few short passages in readers used for the lessons in Finnish. There is no integration to speak of between various disciplines.

The teaching of English

New textbooks contain more material on English-speaking countries other than Britain. About 10-15 per cent of textbook 
chapters deal with U.S. topics. It is not known however how much of this material is actually used in teaching; there is no time to read all the chapters. In addition to the textbooks, teacher-produced material is used extensively in some schools but there is no information about the proportion of American topics dealt with. A significant proportion of the tapes available in Finland are American. In some schools, the pupils are asked to do some extensive reading, and one of the favourite novels is American (The Catcher in the Rye). The importance of extensive reading should not be overemphasized because the novels are discussed at a rather superficial level only. Team work is used to a certain extent to collect material not available in textbooks. Music is often used as a motivating factor; in this area American influence cannot be avoided.

Among the factors affecting the use of American materials, the teacher's initiative and contacts are of primary importance. Active teachers use more materials, and obviously more American materials. If the teacher has had American contacts, either during his training or after, he introduces more American materials. A great majority of the teachers, however, have their major contacts with the English-speaking world in Britain. For geographical reasons this will obviously be the case in the future too, and therefore the English-department syllabuses have been, and will be, very important in creating the right kind of framework for American studies. All Finnish university departments of English teach at least a short survey course of American literature, and their syllabuses include some reading on American institutions and history. As far as American studies are concerned, the situation is worse than a decade ago: we used to have half a dozen Fulbright professors teaching American literature but there are none today. There is only one chair in American studies in Finland: it is the Bicentennial Chair in American Studies established in 1976 for a five-year period at the University of Helsinki. Students may specialize in American studies by writing their M.A. theses on American topics. Most topics falling within this area are literary. Practice teaching, which takes place after graduation, is important in developing future teachers' attitudes towards syllabuses. In some teacher-training schools, team work is used for this purpose, which helps in bringing in U.S. materials.

The matriculation (school-leaving) examination has a strong influence on the contents of teaching. The present examination 
consists of reading comprehension, listening comprehension, and guided composition. With the exception of the listening comprehension test, in which one section is always in American English, tlie texts used are rather general and no American topics are taken up. Both British and American practices are accepted in marking.

Student-interest areas are of great importance in the development of American studies. American exchange students visiting Finland create a right kind of communicative situation for language learning and learning about the U.S. Finnish pupils' visits to the U.S. are similarly important. Visits both ways make it possible to introduce American topics in a natural way. Special events such as the Bicentennial, elections, shows, films, etc. tend to promote the use of American materials.

In most cases the school gives the pupils a rather superficial knowledge of the U.S. The proportion of non-British elements seems to have been on the increase in the last few years.

\section{Research}

There is very little research on American topics. After the Second World War, a few doctoral theses have been written on American literature or history. A research project dealing with Finnish emigration touches upon the U.S. The Department of History at the University of Jyvaskyla has launched a research project based on rather extensive files of American formal documents available on microfilm in Jyvaskyla.

\section{Future prospects}

The reason for English being the primary foreign language in Finland is the fact that English is the major language of international communication. For most pupils the contact with the American way of life is something rather distant, and therefore language teaching easily becomes a game in a fairy world without a connection with reality. The connection with the culture and way of life of the English-speaking countries is important but its importance should not be exaggerated. It is perhaps possible to create a right kind of framework for language studies by integrating them with other disciplines such as literature, history, communication and social studies.

Emphasis on project work will make it possible to concentrate on interdisciplinary themes which are an essential feature in a field such as American studies. At the same time it will be possible to 
develop specific student-interest areas, which is always easier when a topic-based approach is applied. $\mathbf{F}$ there is more concentration on student-interest areas, individualization of teaching is also easier, which again improves the situation in American studies.

In modern language teaching, authentic materials are nowadays preferred to doctored and heavily graded ones. This development favours an interdisciplinary approach, and wider entities, such as American studies, can be taken up. The introduction of the multimedia approach to language teaching has made it possible to build up more authentic settings. 